\title{
Vitamin D supplementation as a fall prevention method: A systematic review
}

\section{Ibrahim Mahmoud Ajwah ${ }^{1}$, Eid Muflih Albalawi ${ }^{1}$, Ziyad Faraj Albalawi ${ }^{1}$, Waad Mohammed}

Alhawiti ${ }^{1}$, Nasser Faris Alahmari ${ }^{1}$, Hanadi Zaydan Albalawi ${ }^{1}$, Talal Khalid Alanazi ${ }^{1}$, Waleed Hamdan Alwabsi $^{1}$, Meshal Faleh Alenezi ${ }^{1}$, Omer Saer Alotaibi ${ }^{1}$, Bdoor Attaulla Alenezi ${ }^{2}$, and Hazem Radi

\section{Rayyan $^{3}$}

1. Internal Medicine Resident, King Salman Armed Forced Hospital, Tabuk, Saudi Arabia

2. Medical Intern, Faculty of Medicine, Northern Border University, Saudi Arabia

3. Internal Medicine and Endocrinology Consultant King Salman Armed Forced Hospital, Tabuk, Saudi

Arabia

\section{RESEARCH}

Please cite this paper as: Ajwah I, Albalawi E, Albalawi Z, Alhawiti W, Alahmari N, Albalawi H, Alanazi T, Alenezi B, Alwabsi W, Alenezi M, Alotaibi O, Rayyan H. Vitamin D supplementation as a fall prevention method: A systematic review. AMJ 2020;13(4):148-155.

https://doi.org/10.35841/1836-1935.13.4.148-155

\section{Corresponding Author:}

Ibrahim Mahmoud Ajwah

King Salman Armed Forced Hospital PO Box 3458 Tabuk 51937, Saudi Arabia

Email: aj.wa@hotmail.com

\section{ABSTRACT}

\section{Background}

Falls are common occurrences events leading to remarkable morbidity and mortality. Vitamin D supplementation is often recommended to prevent falls, although vitamin $D$ trials conclude contradictory results.

\section{Aims}

This review aimed to summarize the available RCTs that studied the effect of vitamin $D$ administered on falls in older adults.

\section{Methods}

Pub Med, Google Scholar, and EBSCO databases were systematically search for relevant articles. The terms vitamin D, falls, ergocalciferols, 25-hydroxy vitamin D, and 1 , 25-dihydroxy vitamin $D$ were used. out of Three hundred and four, only eleven fulfilled the inclusion criteria.

\section{Results}

In the majority of the randomized control trial, vitamin D supplementation provides protection against falls among the elderly population.

\section{Conclusion}

The majority of the studies concluded that vitamin D alone or in combination with calcium was a successful fall reduction method among the elderly.

\section{Key Words}

Vitamin D, falls, ergocalciferols

\section{What this study adds:}

\section{What is known about this subject?}

Studies have shown that vitamin D supplementation improves muscle strength and function, thereby reducing the risk of falls.

\section{What new information is offered in this study?}

Falls reduction can be achieved by daily vitamin $D$ supplementation in doses range between 700-1100IU. While lower daily or higher intermittent dose provide no benefit.

3. What are the implications for research, policy, or practice?

This review did not lead to definite conclusion; an adequate dose of vitamin $D$ supplementation may reduce falls and further study is needed for the definite conclusion.

\section{Background}

According to the World Health Organization, among the elderly, falls are common occurrences events leading to remarkable morbidity and mortality. In the United States, following road traffic injuries, falls considered the second 
leading cause of unintentional injury. ${ }^{1}$

Elderly population particularly at increased risk of vitamin D deficiency as a result of several factors, including but not limited to low dietary intake and diminished sunlight exposure for these reasons, hypovitaminosis $D$ is very frequent in the elder. ${ }^{2,3}$ The association between low level of vitamin D level and increased risk of falls were linked in several studies. For example, the prevalence of low vitamin $D$ in non-faller elderly is ranging between $40-50$ per cent while it is reaching up to 70 per cent in fallers. ${ }^{4,5}$

Vitamin D supplementation has a beneficial effect on muscle strength and balance. Thereby, reduce the occurrence of falls and prevent it is associated morbidity. ${ }^{6}$ On the other hand, insufficient evidence to support the fact that vitamin D supplements especially alone (without supplemental calcium) may have a role in falls prevention. ${ }^{7}$ Given these controversial results, we conducted a systematic review to evaluate the effect of vitamin $D$ administered on falls in older adults.

\section{Method}

A systematic electronic search was conducted including the Pub Med, Google Scholar, and EBSCO using the following terms in different combinations vitamin $D$, falls, ergocalciferols, 25-hydroxy vitamin D, and 1, 25-dihydroxy vitamin D.

Randomized controlled trials in full text that assessed the effects of vitamin D supplementation on risk of falls were included, while abstracts were not included.

Three hundred and four articles were identified, only eleven of them fulfilled the inclusion and exclusion criteria. The abstracts and full texts were screened independently by two authors ( $\mathrm{HO}, \mathrm{Al})$. The authors extracted the data, and then the author's names, year and region of publication, the study type, period of study, and the result were reported. Tables 1 and 2 The PRISMA Chart was used in the current survey (Figure 1).

\section{Results}

Our literature search identified 304 records, 28 of which were reviewed as full-text articles for inclusion. After further exclusions based on our selection criteria, 11 provided sufficient information that was included in the current review. In total, these randomized controlled trials included 6,978 older adults; Study sizes ranged from 122 to 3,717 participants, with the duration of follow-up ranging from one month to 36 months.

\section{Studies prove vitamin D supplementation as falls} prevention methods:

A) Vitamin D alone:

Supplementation of vitamin D alone is proven to reduce the fall occurrence was concluded in a double-blind, placebocontrolled trial carried out by Cangussu et al., ${ }^{8}$ With interventional to control group ratio of $1: 1$, where the interventional group received a daily dose of $1,000 \mathrm{IU}$ of vitamin D.

The dose-dependent effect of vitamin $D$ supplementation on the reduction of falls was evaluated by Broe et al., ${ }^{9}$ Where four different doses of vitamin D (200IU, 400IU, $6001 \mathrm{U}$, or $8001 \mathrm{U}$ ) were compared. A lower falls number was noted in participants receiving $8001 \mathrm{U}$ of vitamin D.

\section{B) Vitamin D plus calcium}

Bischoff et al., ${ }^{10}$ compare the effect of vitamin D supplementation plus calcium versus calcium alone for falls reduction, where the participant randomized to either receive $1.2 \mathrm{~g}$ calcium plus $800 \mathrm{IU}$ cholecalciferol or $1.2 \mathrm{~g}$ calcium. At the end of 12 weeks treatment period, falls reduced by 49 per cent in favour of vitamin $D$ plus calcium supplementation. Similarly, a three-year double-blinded placebo-controlled trial carried out by conducted by the same author Bischoff et al,. ${ }^{11}$ Participants received either 70010 of cholecalciferol plus $500 \mathrm{mg}$ of calcium citrate malate per day or placebo. Supplementation reduces the odds of falling in ambulatory older women by at least 46 per cent.

In Prince, et al study. ${ }^{12}$ A 19 per cent relative risk reduction in the interventional group (ergocalciferol, 1000IU/d plus calcium citrate, $1000 \mathrm{mg} / \mathrm{d}$ ) was concluded from a1-year population-based, double-blind, randomized controlled trial. Alike, 27 per cent at month 12 and 39 per cent at month 20 decrease in the number of subjects with first falls were noted in Pfeifer et al study. ${ }^{13}$

Should Older People in Residential Care Receive Vitamin D to Prevent Falls? In order to answer this question, Flicker et al. $^{14}$ conduct two years randomized, placebo-controlled double-blind, trial in which interventional group receive ergocalciferol, initially 10,000 IU given once weekly and then 1,000 IU daily. Study authors finally conclude that vitamin D supplementation can reduce the number of falls in the elderly. 


\section{Studies deny vitamin D supplementation as falls} prevention methods:

\section{A)-Vitamin D alone:}

Law et al., ${ }^{15}$ Conduct a randomized controlled trial of cluster design. Where the interventional group received ergocalciferol a daily dose of 1,100 IU. After 10 months of follow-up, they found non-significant differencebetween the two study arms.

This result was reinforced in a recent study by Uusi-Rasi et al., ${ }^{16}$ participants were randomly allocated to four study groups, including placebo without exercise, vitamin D $(800 \mathrm{IU} / \mathrm{d})$ without exercise, placebo and exercise, and vitamin D (800IU/d) and exercise. Conclude that vitamin D does not affect the rate of falls.

The effect of high intermittent dose of vitamin $D$ on fall prevention examined as well by Glendenning et al. ${ }^{17}$ In which participants receive oral cholecalciferol 150,000IU every three months and at nine months of the trial, no additive benefit of vitamin $\mathrm{D}$ was seen.

\section{B) Vitamin D plus calcium:}

Burieigh et al., ${ }^{18}$ evaluate the benefit of adding $800 \mathrm{IU}$ of vitamin $\mathrm{D}$ to $1.2 \mathrm{~g}$ of calcium in a randomized, double-blind, controlled study among hospitalized patients, aimed to determine whether vitamin D supplementation has an effective role in falls prevention in older hospital inpatients. Vitamin D did not reduce the number of fallers. Routine supplementation cannot be recommended to reduce falls in this group.

\section{Discussion}

The current review summarizes eleven randomized control trials evaluated the hypothesized possible beneficial effect of vitamin $D$ in isolation as well as in combination with calcium supplement on falls reduction.

A significant reduction was concluded in seven studies. Despite the different dosage of vitamin $D$ were used in these studies (200-1000IU), a significant reduction was associated with a dose of $700 \mathrm{IU}$ and higher. ${ }^{8-14}$

As an example, Broe et al., studied different doses of vitamin $D$ supplement and only participants who receive $800 \mathrm{IU}$ of vitamin D, had a lower incidence of falls compared to those who take a lower dose. ${ }^{9}$

Many evidences suggest that vitamin D in combination with calcium supplementation has a beneficial role in falls prevention. Four out of seven studies combined calcium to the vitamin D supplement. ${ }^{10-13}$

As an illustration, Bischoff et al. found a reduction of falls with vitamin D - calcium supplement in the community elderly. ${ }^{10,11}$ But in these studies, the effect of calcium and vitamin $D$ could not be separated. In another systemic review, Haiting and Qingjiang found that combined calcium plus vitamin D supplementation are statistically significantly associated with a reduction in fall risks across various populations. Finally, the current evidence for the effect of supplementary vitamin D alone on fall outcomes is limited. ${ }^{19}$ On the other hand, in this review, four studies found that no reduction in risk of falls neither with vitamin $D$ alone nor in combination with calcium. ${ }^{15-18}$

In one of these studies. Glendenning et al used higher doses of vitamin D (cholecalciferol 150,000IU every three months) and found that it is ineffective or deleterious on the risk of falls. ${ }^{17}$ This result was also supported in a randomized control trial conducted by Bischoff et al., in 2016 when they compared low versus high doses of vitamin D. The study showed an increased risk of falls were associated with the usage of higher doses. ${ }^{20}$

The results of the pooled studies are limited and cannot be generalized, as the studies participants were mainly community dwelling and hospitalized elderly.

To summarize, controversial results were found between studies. However. These contradictory results may be related to the variation in the baseline serum vitamin $D$ levels between studies participants. Furthermore, the usage of different vitamin $D$ doses among the interventional group.

\section{Conclusion}

In conclusion, the majority of the studies concluded that vitamin $\mathrm{D}$ alone or in combination with calcium was a successful fall reduction method among the elderly.

\section{References}

1. World Health Organization. Falls. Available from: http://www.who.int/mediacentre/factsheets/fs344/en

2. Smith G, Wimalawansa SJ, Laillou A, et al. High prevalence of vitamin $D$ deficiency in cambodian women: a common deficiency in a sunny country. Nutrients. 2016. doi:10.3390/nu8050290

3. Holick MF, Binkley NC, Bischoff-Ferrari HA, et al. Evaluation, treatment, and prevention of vitamin $D$ deficiency: an Endocrine Society clinical practice guideline. J Clin Endocrinol Metab. 2011;96(7):1911-30. 
4. Stein MS, Wark JD, Scherer SC, et al. Falls relate to vitamin $\mathrm{D}$ and parathyroid hormone in an Australian nursing home and hostel. J Am Geriatr Soc. 1999;47(10):1195-201.

5. Thomas MK, Lloyd-Jones DM, Thadhani RI, et al. Hypovitaminosis D in medical inpatients. N Engl J Med. 1998;338(12):777-83.

6. Tang BM, Eslick GD, Nowson C, et al. Use of calcium or calcium in combination with vitamin $\mathrm{D}$ supplementation to prevent fractures and bone loss in people aged 50 years and older: a meta-analysis. Lancet. 2007;370:657666.

7. Latham NK, Anderson CS, Reid IR. Effects of vitamin D supplementation on strength, physical performance, and falls in older persons: a systematic review. J Am Geriatr Soc. 2003;51:1219-1226.

8. Cangussu L, Nahas-Neto J, Orsatti C, et al. Effect of isolated vitamin $D$ supplementation on the rate of falls and postural balance in postmenopausal women fallers. Menopause. 2016;23(3):267-274.

9. Broe K, Chen T, Weinberg J, et al. A higher dose of vitamin $D$ reduces the risk of falls in nursing home residents: A randomized, multiple-dose study. J Am Geriatr Soc. 2007;55(2):234-239.

10. Bischoff H, Stahelin H, Dick W, et al. Effects of vitamin D and calcium supplementation on falls: $A$ randomized controlled trial. J Bone Miner Res. 2003;18(2):343-351.

11. Bischoff-Ferrari H. Effect of cholecalciferol plus calcium on falling in ambulatory older men and women: A 3-year randomized controlled trial. Arch Int Med. 2006;166(4):424-430.

12. Prince R. Effects of ergocalciferol added to calcium on the risk of falls in elderly high-risk women. Arch Int Med. 2008;168(1):103.

13. Pfeifer $M$, Begerow B, Minne $H$, et al. Effects of a longterm vitamin $D$ and calcium supplementation on falls and parameters of muscle function in communitydwelling older individuals. Osteoporos Int. 2008;20(2):315-322.

14. Flicker L, Maclnnis R, Stein M, et al. Should Older People in Residential Care Receive Vitamin D to Prevent Falls? Results of a Randomized Trial. J Am Geriatr Soc. 2005;53(11):1881-1888.

15. Law M, Withers $H$, Morris J, et al. Vitamin D supplementation and the prevention of fractures and falls: results of a randomised trial in elderly people in residential accommodation. Age and Ageing, 2006;35(5):482-486.

16. Uusi-Rasi K, Patil R, Karinkanta $S$, et al. Exercise and vitamin $D$ in fall prevention among older women. JAMA Inter Med. 2015;175(5):703.
17. Glendenning $\mathrm{P}$, Zhu K, Inderjeeth $\mathrm{C}$, et al. Effects of three-monthly oral 150,000 IU cholecalciferol supplementation on falls, mobility, and muscle strength in older postmenopausal women: A randomized controlled trial. J Bone Miner Res. 2011;27(1):170-176.

18. Burleigh E, McColl J, Potter J. Does vitamin D stop inpatients falling? A randomised controlled trial. Age and Ageing. 2007;36(5):507-513.

19. Haiting W, Qingjiang P. The effect of vitamin D and calcium supplementation on falls in older adults: $A$ systematic review and meta-analysis. Der Orthopäde. 2017;46. 10.1007/s00132-017-3446-y.

20. Bischoff-Ferrari HA, Dawson-Hughes B, Orav EJ, et al. Monthly high-dose vitamin $D$ treatment for the prevention of functional decline: $A$ randomized clinical trial. JAMA Inter Med. 2016;176:1-10. 10.1001/jamainternmed.2015.7148.

\section{ACKNOWLEDGEMENTS}

We deeply thank Mrs. Amal Bedaiwi for her grateful advice and assistance in keeping our progress on schedule.

\section{CONFLICTS OF INTEREST}

The authors declare that they have no competing interests.

\section{FUNDING}

None 
Figures and Tables

Table 1: Randomized control trials with proven effect of vitamin D supplementation to reduce the risk of falls

\begin{tabular}{|c|c|c|}
\hline $\begin{array}{c}\text { Author-Year } \\
\text { Country }\end{array}$ & Methods & Results \\
\hline $\begin{array}{l}2015 \\
\text { Brazil }\end{array}$ & $\begin{array}{l}\text { Study design: Randomized, double-blind, } \\
\text { placebo-controlled trial } \\
\text { Inclusion criteria: Date of last menstruation } \\
\text { at least } 12 \text { months before, aged } 50 \text { to } 65 \\
\text { years, history of falls in the last } 12 \text { months, } \\
\text { and with bone mineral density (BMD) } \\
\text { higher than S1.5 SD. } \\
\text { Interventional group: } 1,000 \text { IU/day/orally } \\
\text { Follow-up: } 9 \text { months } \\
\text { Primary objective: To evaluate the effect of } \\
\text { isolated vitamin D supplementation on the } \\
\text { occurrence of falls }\end{array}$ & $\begin{array}{l}\text { Study completer: } 140 \text { Women } \\
\text { Primary objective: The occurrence of falls and falls } \\
\text { recurrence was higher in the placebo group compared to } \\
\text { the VITD group }(P<0.001) \text {. } \\
\text { Limitation: Representative study } \\
\text { Conclusion: Isolated vitamin D supplementation for } 9 \\
\text { months resulted in a lower incidence of falls. }\end{array}$ \\
\hline $\begin{array}{c}\text { Broe et al. }^{9} \\
2007 \\
\text { Massachusetts }\end{array}$ & $\begin{array}{l}\text { Study design: Double-blind, placebo- } \\
\text { controlled trial } \\
\text { Inclusion criteria: Life expectancy of } 6 \\
\text { months, ability to swallow medication. } \\
\text { Interventional group: Vitamin D (200IU, } \\
\text { 400IU, 600IU, 800IU) } \\
\text { Follow-up: } 5 \text { months } \\
\text { Primary objective: occurrence of falls. }\end{array}$ & $\begin{array}{l}\text { Study completer: } 124 \text { participants } \\
\text { Primary objective: Low rate of falls among residents in } \\
\text { 800IU vitamin D supplement group. } \\
\text { Limitation: use on multivitamins and result cannot be } \\
\text { generalized. } \\
\text { Conclusion: Adequate vitamin D supplementation in } \\
\text { elderly nursing home residents could reduce the number } \\
\text { of falls experienced by this high fall risk group. }\end{array}$ \\
\hline $\begin{array}{l}\text { Bischoff-Ferrari et al. }^{11} \\
2006\end{array}$ & $\begin{array}{l}\text { Study design: Randomized, double-blind } \\
\text { placebo-controlled trial } \\
\text { Inclusion criteria healthy ambulatory men } \\
\text { and women } 65 \text { years or older and living in } \\
\text { the community. } \\
\text { Interventional group: Cholecalciferol } \\
\text { (vitamin D3; 700IU/d) plus calcium } \\
(500 \mathrm{mg} / \mathrm{d}) \text {. } \\
\text { Follow-up: } 3 \text { years }\end{array}$ & $\begin{array}{l}\text { Study completer: } 445 \text { individuals } \\
\text { Primary objective: Cholecalciferol-calcium significantly } \\
\text { reduced the odds of falling in women, but not in men. } \\
\text { Limitation: The result cannot be generalized. } \\
\text { Conclusion: Long-term dietary cholecalciferol-calcium } \\
\text { supplementation reduces the odds of falling in } \\
\text { ambulatory older women by } 46 \% \text {. }\end{array}$ \\
\hline
\end{tabular}




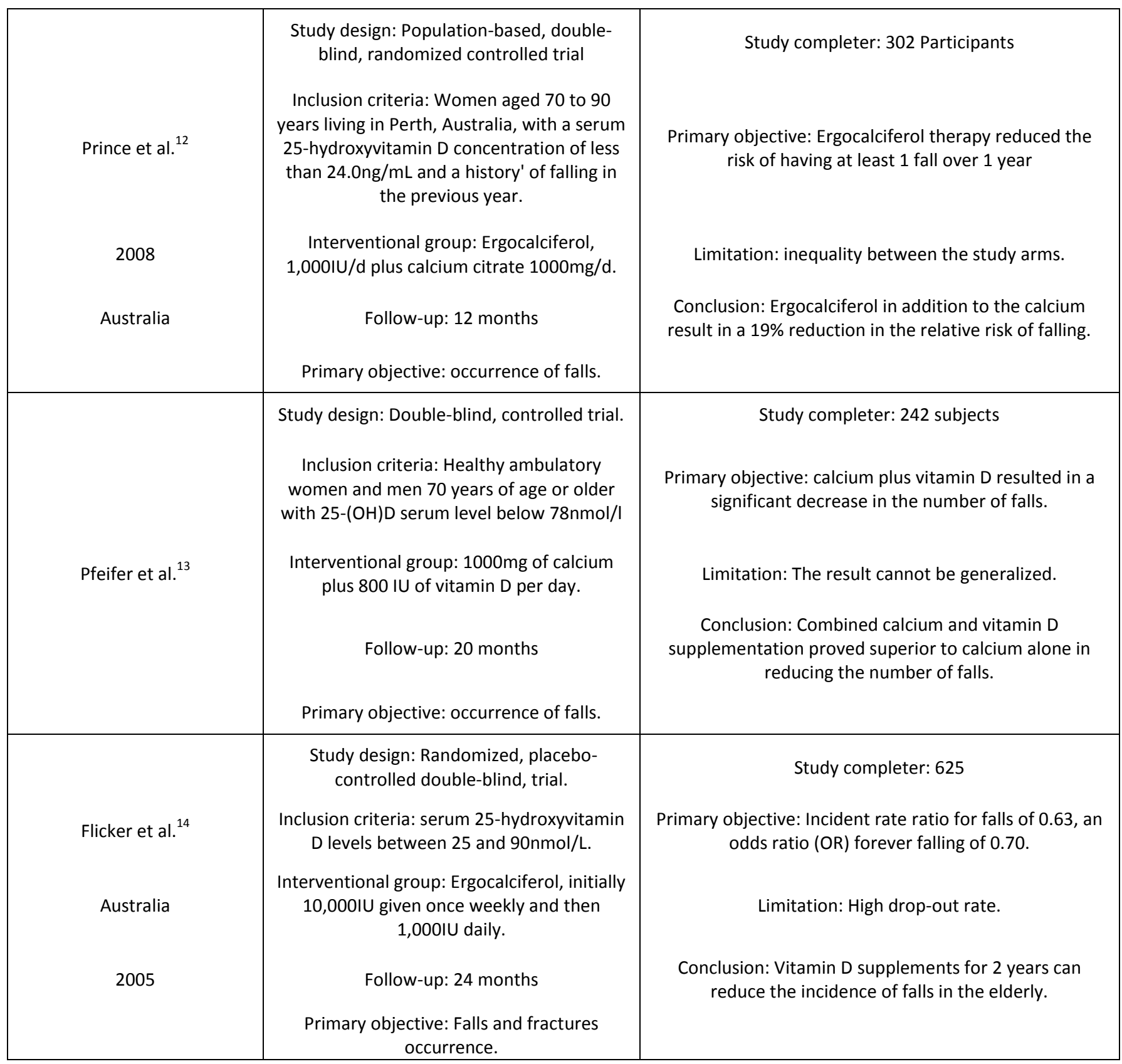

Table 2: Randomized Control Trial that showed no role of vitamin D in reduces the risk of falls

\begin{tabular}{|c|c|c|}
\hline $\begin{array}{c}\text { Author-Year } \\
\text { Country }\end{array}$ & Methods & Results \\
\hline $\begin{array}{c}\text { Malcolm Law et al. } \\
\\
2006\end{array}$ & $\begin{array}{c}\text { Study design: Randomized } \\
\text { controlled trial of cluster design } \\
\text { Inclusion criteria: Age } \geq 60 \text { years old } \\
\text { and Not taking calcium/vitamin D } \\
\text { or drugs that increase bone } \\
\text { density. } \\
\text { Interventional group: Ergocalciferol } \\
2.5 \mathrm{mg} \text { every } 3 \text { months. }\end{array}$ & $\begin{array}{l}\text { Study completer: 3,717 participating residents } \\
\text { Primary objective: Falls among the study arms not } \\
\text { statistically significant. } \\
\text { Limitation: Reporting error. }\end{array}$ \\
\hline British & $\begin{array}{l}\text { Follow-up: } 10 \text { months } \\
\text { Primary objective: Falls and } \\
\text { fracture. }\end{array}$ & $\begin{array}{c}\text { Conclusion: No evidence that vitamin D prevents fractures } \\
\text { or falls in elderly people in care home accommodation }\end{array}$ \\
\hline
\end{tabular}




\begin{tabular}{|c|c|c|}
\hline 2015 & $\begin{array}{l}\text { Study design: Randomized, double- } \\
\text { blind, placebo-controlled trial. } \\
\text { Inclusion criteria: At least } 1 \text { fall } \\
\text { during the previous year, no use of } \\
\text { vitamin D supplements, and no } \\
\text { contraindication to exercise. } \\
\text { Interventional group: Four study } \\
\text { groups, including placebo without } \\
\text { exercise, vitamin D ( } 800 \text { IU/d) } \\
\text { without exercise, placebo and } \\
\text { exercise, and vitamin D ( } 800 \mathrm{IU} / \mathrm{d}) \\
\text { and exercise. } \\
\text { Follow-up: } 2 \text { years. } \\
\text { Primary objective: monthly } \\
\text { reported falls. }\end{array}$ & $\begin{array}{l}\text { Study completer: } 370 \text { participants } \\
\text { Primary objective: No falls reduction. } \\
\text { Limitation: Elevated baseline } 25(\mathrm{OH}) \mathrm{D} \text { levels. } \\
\text { Conclusion: vitamin D does not affect the rate of falls. }\end{array}$ \\
\hline $\begin{array}{c}\text { Glendenning et al. }{ }^{17} \\
2012 \\
\text { Australia }\end{array}$ & $\begin{array}{l}\text { Study design: Randomized, } \\
\text { double-blind, placebo-controlled, } \\
\text { prospective, parallel study } \\
\text { Inclusion criteria: age over } 70 \\
\text { years, registration with a general } \\
\text { practitioner, and likelihood, in the } \\
\text { investigators' opinion, of attending } \\
\text { four study visits over } 9 \text { months } \\
\text { Interventional group: } \\
\text { Cholecalciferol } 150,000 \text { IU of } \\
\text { vitamin D every } 3 \text { months } \\
\text { Follow-up : } 9 \text { months } \\
\text { Primary objective: Falls occurrence. }\end{array}$ & $\begin{array}{l}\text { Study completer: } 686 \text { participants } \\
\text { Primary objective: Faller rates in the two groups did not } \\
\text { differ } \\
\text { Limitation: The result cannot be generalized. } \\
\text { Conclusion: Intermittent large doses of vitamin D are } \\
\text { ineffective or have a deleterious effect on falls }\end{array}$ \\
\hline Burleigh et al. ${ }^{18}$ & $\begin{array}{l}\text { Study design: Prospective, } \\
\text { randomized, double-blind, } \\
\text { controlled study. } \\
\text { Inclusion criteria: Patients } \\
\text { transferred or admitted into the } \\
\text { general assessment and } \\
\text { rehabilitation wards in an acute } \\
\text { geriatric unit were screened for } \\
\text { eligibility for trial entry. } \\
\text { Interventional group: vitamin D } \\
\text { 800IU plus calcium 1,200mg } \\
\text { Follow-up: } 1 \text { month } \\
\text { Primary objective: Falls occurrence. }\end{array}$ & $\begin{array}{l}\text { Study completer: } 205 \text { Participants. } \\
\text { Primary objective: no reduction in the number of falls } \\
\text { Conclusion: Population of geriatric hospital inpatients, } \\
\text { vitamin D did not reduce the number of fallers. Routine } \\
\text { supplementation cannot be recommended to reduce falls } \\
\text { in this group. }\end{array}$ \\
\hline
\end{tabular}


Figure 1: Flow diagram through the different phases of the systematic review (PRISMA flowchart)
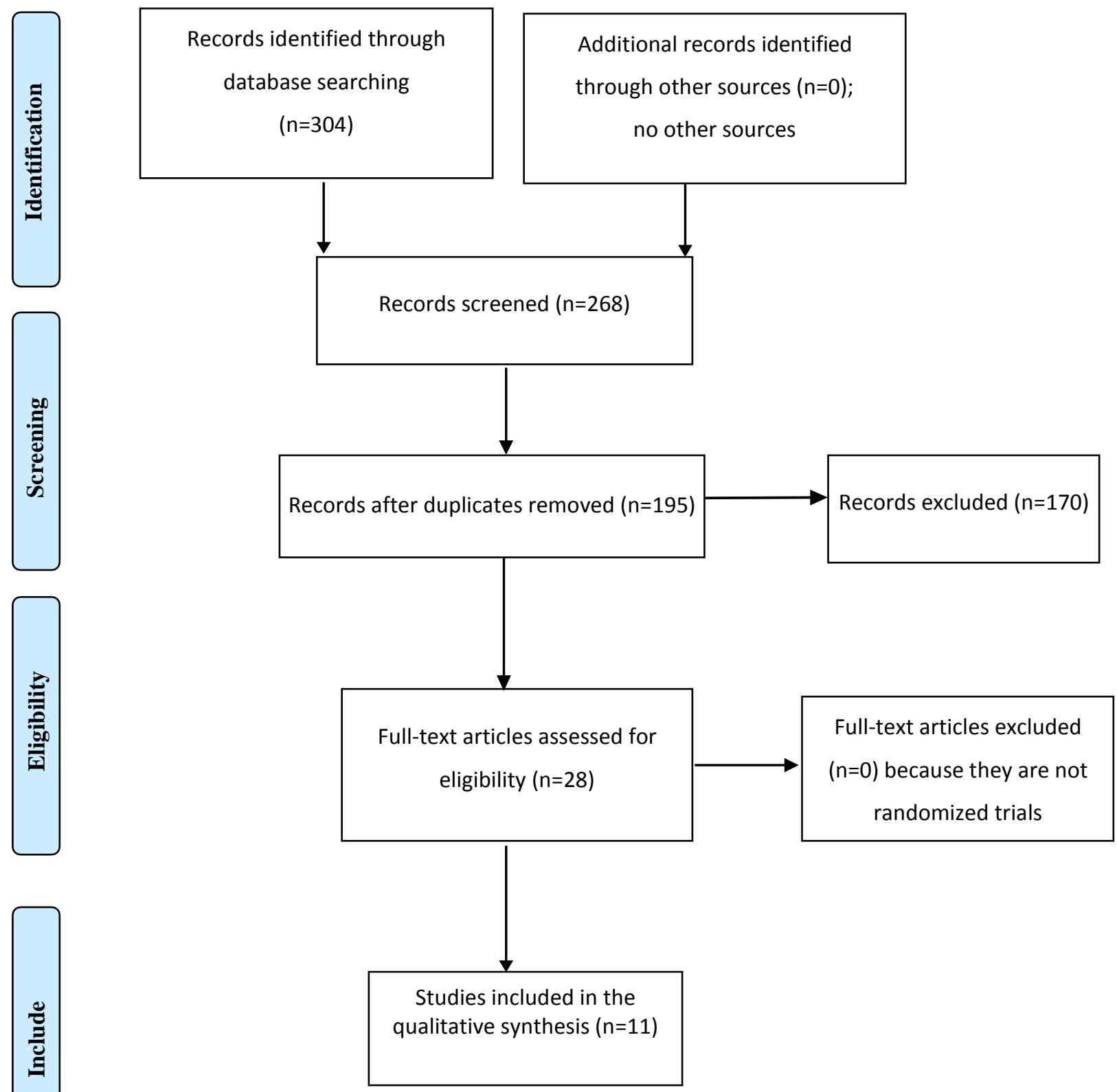